\title{
SZIKSZAi MÁRIA*
}

\section{VALLÁSOS TÁRSULATI ÉLET EGY SZATMÁRI SVÁB FALUBAN ${ }^{* *}$}

\begin{abstract}
Kulcsszavak: mindennapi élet, helyi vallásosság, vallásos társulatok, Kaplony, XX. század, terepmunka
\end{abstract}

Kaplony ${ }^{1}$ a romániai Szatmár megyében, Nagykárolytól 4 km-re, az egykori Ecsedi-láp közelében fekszik.

A 18. században gróf Károlyi Sándor több hullámban telepített ide svábokat. ${ }^{2}$ A valamikori sváb falu mára már szinte teljesen elmagyarosodott. A 2002-es népszámlálási adatok szerint Kaplony 4511 lakosából 3760 magyar, 161 román, 156 roma és 433 német nemzetiségűnek vallotta magát, egy személy nem nyilatkozott nemzetiségi hovatartozásáról. Vallásilag a lakosság a következőképpen oszlik meg: 4080 római katolikus, 300 református, 84 ortodox és 46 görög katolikus és egy személy unitárius vallású. ${ }^{3}$

Kaplony régi templomainak helyén épült a mai templom. Állítólag 1080-ban bencés monostor és templom állt a faluban. ${ }^{4}$ Károlyi gróf 1711 után újraépíttette a régi templomot, amely 1834-ben egy földrengés alkalmával összeomlott. Ennek helyére építették és 1848-ban szentelték fel a mai Szent Antal plébániatemplomot.

A svábok betelepítésekor már rendházuk volt Kaplonyban a ferences szerzeteseknek. A betelepítettek lelki gondozását a ferencesekre bízták. A XX. század második feléig folytonos volt a ferencesek jelenléte. 2008. augusztus elsejétől újra jelen vannak a faluban, és átvették a Szent Antal plébánia irányítását is.

Kaplonyi kutatásaimat 1995-1996 között, majd 2006 óta folytatom. A jelen kutatás célja a Szatmár megyei sváb eredetű katolikus kisközösség vallásos gyakorlatának, ezen belül a vallásos testületek, társulatok jelenlétének, müködésének, ezek történeti vetületeinek vizsgá-

* Szirszai Mária a kolozsvári BBTE magyar nyelv és irodalom-néprajz szakán szerzett diplomát, majd ugyanitt magiszteri és 2004-ben doktori címet. Jelenleg a Magyar Néprajz és Antropológia Intézet adjunktusa. Kutatási területei: múvészetantropológia, szakrális múvészet, vallásos társulatok.

* A kutatást a MTA Domus kutatási programja támogatta 2013-ban.

1 Căpleni (rom.), Kaplau (ném.) - Szatmár megye, Románia

2 1996-ban megjelent a falu monográfiája: Tempfli Imre: Kaplony. Adalékok egy honfoglaláskori település történetéhez. Szent-György Albert Társaság és a Szatmár megyei EMKE, Szatmárnémet, 1996.

3 http://recensamant.referinte.transindex.ro/?pg=3\&id=2145

4 Egy recens régészeti felfedezés alátámasztani látszik ezt: a templom egyik belső fala a régészek szerint román korból származik. A leletről és jelentőségéről Mircea Drăgan, a Szatmár Megyei Kulturális és Örökségvédelmi Igazgatóság munkatársa informálta a helyszínen a sajtó képviselôit. http://www.frissujsag.ro/felfedezes-a-kaplonyi-ferenceseknel/ Lekérdezés dátuma: 2013. június 15. 
lata. A legtöbb Kaplonyban megjelenő vallásos társulat a XX. század első felében múködött, ebből az időszakból vannak írásos nyomai. ${ }^{5}$

Munkám egyik forrása a helyi plébánián őrzött Historia Domus volt, amelyet 1885 és 1986 között vezettek. Felhasználtam továbbá fennmaradt korabeli iratokat: levelezéseket, számadási íveket, nyilvántartásokat, elismervényeket, nyugtákat, egyéb feljegyzéseket, amelyek a vallásos életre utaló adatokat tartalmaztak. Közvetlen adatgyüjtést végeztem néhány falubeli családnál. Fényképeztem a birtokukban levő iratokat, képeket. Ezek nagy része a felmenőik vallási társulati tagságát igazolják. Ezekkel egy helyen tartják az imakönyveiket, az idők során ajándékba kapott kis méretű szentképeket, kéziratos, írógéppel írt vagy nyomtatott formában terjesztett imákat. A fényképezés közben félig irányított beszélgetést folytattam az adatközlőkkel, majd azt követően célzott kérdéseket tettem fel a társulati életről. 2006 óta minden évben folytattam terepkutatást, és részt vettem a falu legalább egy búcsúján (legtöbbször a Porciunkula búcsún augusztus elején), illetve többször elkísértem a falubelieket a szomszédos Kálmánd község Szent Anna-napi búcsújára.

\section{VALLÁSOS TÁRSULATOK}

A Historia Domusban olvasható bejegyzés szerint 1906-ban a szatmárnémeti káptalani helyettes megdicsérte a kaplonyi lelkipásztor tevékenységét, melynek nyomán „sok jámbor társulat” múködik a faluban, bár ezeket közelebbről nem nevezi meg. (Histora Domus, továbbiakban HD, 48. old.) Valóban, már eddig az időpontig is léteztek a faluban katolikus vallásos társulatok, ezek száma azonban ezt követően tovább növekszik.

\section{RÓZSAFÜZÉR-TÁRSULATOK. ÖRÖKÖS RÓZSAFÜZÉR TÁRSULAT, ÉLŐ RÓZSAFÜZÉR TÁRSULAT}

1894-ben a Historia Domus feljegyzése szerint a püspök tudomásul vette a kaplonyi plébános november 14-én előterjesztett jelentését a helyi Rózsafüzér-társulat megalakításáról, és felhatalmazza a plébánost, hogy a társulatot vezesse és igazgassa. ${ }^{6}$

1899. március 15-én jelzi a Historia Domus írója, hogy a Rózsafüzér-társulat múködését a Domonkos-rend még nem erősítette meg, ezért intézkedést foganatosítottak: „A Kaplonyban

5 A tanulmányban a következő bibliográfiát használtam fel: Beszédes Valéria: Szent Antal tisztelete Szabadkán. Néprajzi Látóhatár VI. 1997. 427-433; Historia Domus. Kaplony, 1885-1940; P. MaRTini Fortunát: Páduai Szent Antal Imaegyesületének felvételi könyvecskéje. KolLÁr Antal és fia könyvnyomdája, Baja, 1902; P. Soós István: Hóvirágot a kis Jézuskának. Kilencedik, változatlan kiadás. Egyházmegyei könyvnyomda, Veszprém, 1910; (szerző nélkül): (Rövid értesités szent József társulatáról). é. n.; Tánczos Vilmos: (a) A Szent Kereszt Hadserege egy moldvai csángó faluban (Bogdánfalvában). Egyházfórum (Pécs) XIX. (V). 2004. 5. 11-15; Tánczos Vilmos: (b) Erdély János (1891-1983) bogdánfalvi szentember és népénekei. Székelyföld. VII. 2004. 10. 126-144; TEMPfLI Imre: Kaplony. Adalékok egy honfoglaláskori település történetéhez. Szent-György Albert Társaság és a Szatmár megyei EMKE Kiadók, Szatmárnémeti, 1996.

6 Historia Domus 13. 
már évek óta létező, de a Dominikánusoktól megerősítve nem levő »Örökös Rózsafüzér Társulat « felterjesztetett megerősítés és jóváhagyás végett a főt. Domonkos Rend tartományi hivatalának Bécsbe, melyben egyuttal az is van kérve, hogy annak igazgatásával az időszerinti házfönök és lelkész bizassék meg” 7

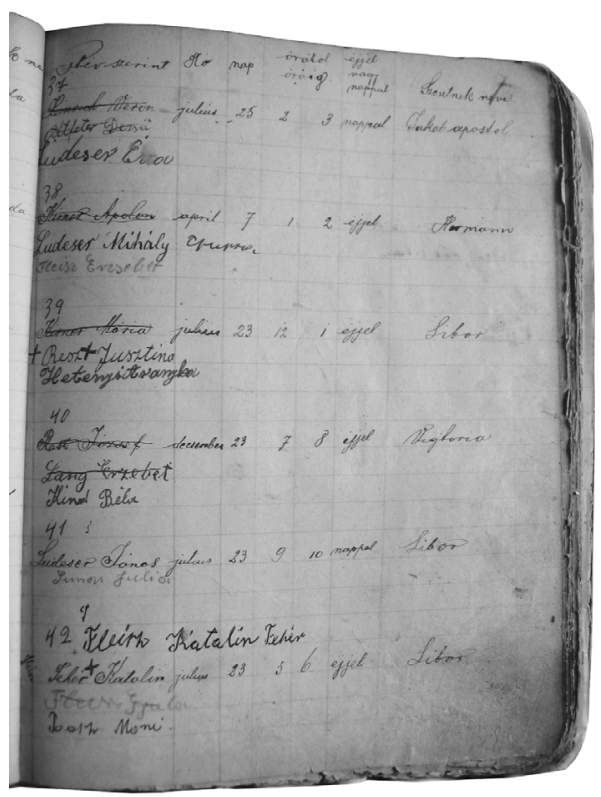

1. kép

Az Örökös Rózsafüzér Társulat két füzete megtalálható a plébániai irattárban. ${ }^{8}$ Évszámot nem tudtunk felfedezni a füzetekben, így csak következtetni tudunk a keletkezésük időpontjára. Az egyik mindenképpen a XX. század második felében keletkezhetett, ugyanis az abban szereplő személyek közül sokan ma is élnek. Néhány esetben sikerült az imamondás időszakait is visszaigazolni az adatközlők körében. A füzetbe bejegyezték azt is, ha az elhunyt tagtól egy családtagja átvette, vagy ahogy a helyiek mondják, örökölte az imamondás alkalmát. Ilyen esetekben a kézzel beírt nevet áthúzták, és alája ugyancsak kézzel odaírták az új személy nevét. Vannak olyan oldalak, ahol három ilyen nevet is látunk egymás alatt. Ebből jól látszik, hogy legalább három generációig követhetôk vissza az imamondás alkalmai. Az adatközlők közül többen is elmondták, hogy szüleiktől, nagyszüleiktől így örökölték a saját időpontjaikat.

\section{LEGÉNYEGYLET, LEÁNYEGYLET}

1912-ben a nagykárolyi legényegylet megalakulásának 25. évfordulója alkalmából ünnepséget szerveztek Nagykárolyban. Ugyanakkor a legényegylet új székházba költözött. (HD 64) Igaz, hogy ez nem kaplonyi adat, de a közelsége okán releváns lehet. Az ünnepségnek feltehetően hatása volt a környékbeli folyamatokra, hiszen az ünnepségen a környék papsága is részt vett.

Egy 1932. február 11-i jegyzőkönyvből kiderül, hogy hatvan kaplonyi leány jelenlétében megalakították a Kis Szent Teréz Leányegyletet. Ugyancsak 1932-ben, február 24-én Katolikus legényegylet is alakult Kaplonyban, az Adolf Kolping-féle legényegylet mintájára, feltehetően annak szabályzata alapján. Az irattárban ugyanis megtalálható a legényegylet szabályzatát tartalmazó 1895-ben megjelent brosúra, amely A kathol. legényegyleti tag jogainak és kötelességeinek megismertetése címet viseli, és amelyet Msgr. Krönes Ferenc nyomán Schiffer Ferenc központi elnök adott ki.

7 Historia Domus 29.

8 Lásd az 1. számú képet: részlet az Örökös Rózsafüzér Társulat nyilvántartási könyvéből. 
1941. május 2-án Katolikus Agrárifjúsági Legényegyletet (KALOT) is alakítottak Kaplonyban, amely múködését a Magyar Királyi Belügyminisztérium 1941. augusztus 5-én hagyta jóvá.

A mai 80 éves adatközlők nagyobb testvéreikről mesélik, hogy tagjai voltak a leányegyletnek és a legényegyletnek 18-20 éves koruk táján. Emlékeik szerint a fiúk hazafias dalokat tanultak, a lányok kézimunkáztak az összejöveteleken.

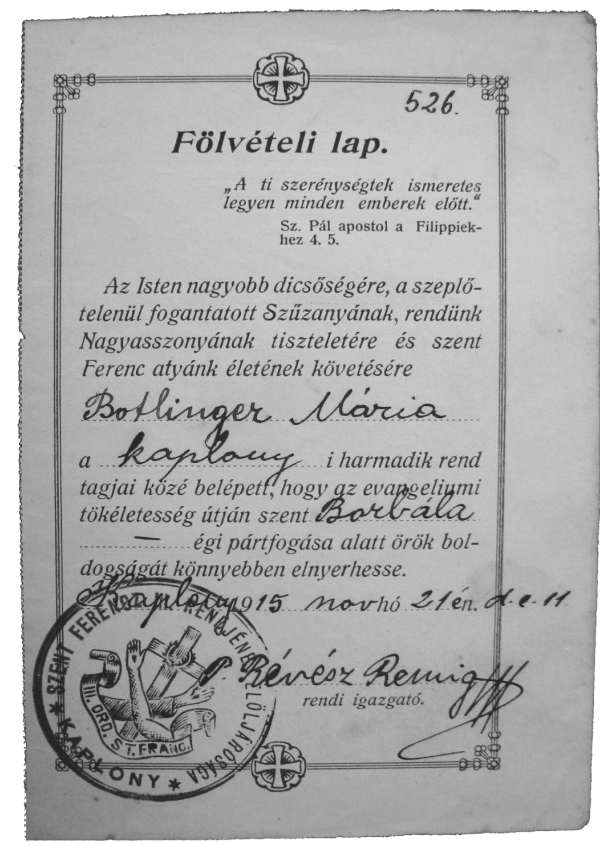

2. kép

\section{FERENCES HARMADREND}

Nem derült ki még az, hogy mióta múködik a ferences harmadrend a faluban. Azt tudjuk csupán, hogy a ferences szerzetesek a svábok betelepítésekor a XVIII. század elején már ott voltak Kaplonyban. Néhány adatot tudunk említeni a harmadrend XX. század eleji taglétszámával kapcsolatban: 1917-1921 között 98 tagot tartottak nyilván, 1922-1933 között pedig 90 tagot. 1928-ban megemlítik, hogy növekszik a szentáldozásban részesülők száma, „különösen a harmadrend tagjai járultak gyakorta az Úr asztalához". ${ }^{9}$

A kaplonyi plébánia irattárában megtalálható pár fölvételi lap ${ }^{10}$, másokat a jelenlegi tagok vagy azok leszármazottjai az otthonukban őriznek.

Jelenleg is vannak ferences harmadrendűek a faluban, bár számuk nem éri el a húszat. A tagságról adatokat tartalmazó nyilvántartási könyv a ferences harmadrend vezetőjénél található. Ebbe feljegyzik a személyes adatait, azt, hogy mikor lépett be a harmadrendbe, és a megjegyzések rovathoz azt is, hogy mennyire aktív az illető, vagy ellenkezőleg, betegsége okán nem tud részt venni az összejöveteleken.

A 89-es fordulat előtti években is léptek be kaplonyiak a harmadrendbe, bár ezeket a beavatásokat csak titokban tudták megtartani. A jelenlegi tagok kizárólag a nagyon idősek generációjából vannak, fiatalok teljesen hiányoznak. Korábban tevékenységük abban állt, hogy havonta egyszer a lelki vezetőjük összehívta őket, és beszédet tartott nekik egy adott bibliai témáról. A kaplonyi harmadrend tagjai olykor részt vettek a többi erdélyi harmadrendi részvételével szervezett találkozókon is. Azonban az utóbbi években ezek a tevékenységek már nem folytatódtak, és ezt főleg a tagság elöregedésével lehet magyarázni.

9 Historia Domus 105.

10 Lásd a 2. számú képet: Botlinger Mária kaplonyi lakos fölvételét igazoló ferences harmadrendi irat 1915-ből. A kaplonyi ferences kolostor irattárából. 


\section{JÉZUS SZÍVE TÁRSULAT, MÁRIA TÁRSULAT}

A húszas években múködött Kaplonyban a Jézus Szent Szíve és a Mária Társulat. 1927 márciusában a hitélet fellendítéséért a kaplonyi plébános gyúléseket tartott a különböző társulatoknak: a ferences harmadrendieknek a hónap első vasárnapján, a Jézus Szíve Társulatnak a második vasárnapon, a Mária Társulatnak pedig a harmadik vasárnapon. Ezeken az alkalmakon nagy számban jelentek meg a hívek. ${ }^{11}$

Nincsen alakulási adatunk, ám az 1929. és 1930. évi pénzügyi számadásokban megjelenik a Jézus Szent Szíve Társulat is, ami bizonyítja a társulat múködését ebben az időszakban, hiszen a tagjai tagdíjat fizettek.

Az 1929., 1930. és 1932. évi plébániai pénzügyi számadásokban az Örökös Rózsafüzér Társulat adatai mellett szerepelnek a Mária Testvérületi Társaság bevételi és kiadási adatai is. Valószínúleg Mária Testvérületi Társaság néven jelölik a Mária Társulatot. Bár utalást a működésükre már 1927-ből találtunk, megalakulási idejéról nem bukkantak fel adatok. Bevételei tagdijakból és perselypénzből származnak, kiadásai között két tétel szerepel: havi misékért fizetnek, illetve az elhunyt társulati tagokért mondott misékért.

Mint említettük, a plébánia levéltárában fellelhető jegyzőkönyvek, szabályzatok, belépési lapok mellett fontos forrásanyagot jelentenek az adatközlők tulajdonában levő anyagok, például a saját és felmenőik társulati belépési könyvecskéi. 2012 nyarán Fleisz Ilona és Margit testvérek közös háztartásában hét olyan társulati könyvecskét találtam, amelyek a saját, illetve a felmenő családtagjaik belépését regisztrálták. Ezt követően 2013-ban előkerült egy nyolcadik társulati lap is tőlük.

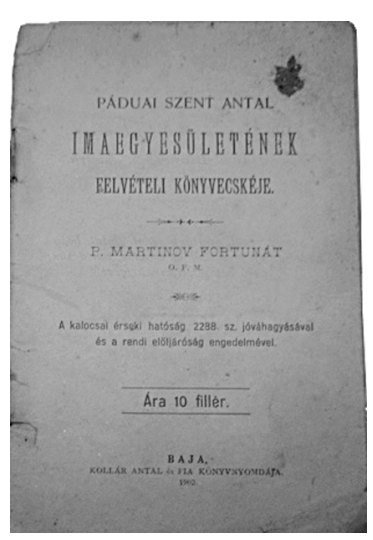

3. kép

\section{PÁDUAI SZENT ANTAL IMAEGYESÜLET}

Az imaegyesület népszerű lehetett Kaplonyban, hiszen Páduai Szent Antal tiszteletére szentelt temploma van a falunak, és legfontosabb búcsúnapja is június 13-án, a Páduai Szent Antal ünnepén van.

A kaplonyi Páduai Szent Antal Imaegyesület megalakulásának pontos adata még nem ismert. Egyik kaplonyi család tulajdonában van egy tagsági iratként is funkcionáló, 1902-ben kiadott felvételi könyvecske. ${ }^{12} \mathrm{~A}$ kiadvány végén az utolsó oldalak egyikén lenne helye a belépő tag nevének, ám ezt az oldalt nem töltötték ki.

11 Historia Domus 105.

12 Lásd a 3. sz. képet: Páduai Szent Antal Imaegyesület könyvecskéje, F. I. és F. M. tulajdonában levő irat. 


\section{AZ ÉLŐ KERESZTÚT TÁRSULATA}

A kaplonyi tagsági könyvecske megfelelő része nincsen kitöltve a tag nevével, így ez esetben sem tudni, kinek a belépése alkalmával került a család ${ }^{13}$ tulajdonába.

A 28 oldalas kiadvány 1909-ben jelent meg Pécsen, a pécsi Szent Ferenc zárda adta ki. A társulat kaplonyi jelenléte nyilván kapcsolatban van a helyi ferencesekkel, hiszen nekik volt joguk létrehozni ezt a társulatot.

Szakirodalmi adataink is arra utalnak, hogy más helyeken is a ferencesek jelenlétéhez köthető a társulat. Péter Jánosné Pásztor Erzsébet búcsúvezető asszonyról írja Csáky Károly: „Társulati könyvei közt volt az Élő Keresztút Társulatának szabálykönyvecskéje is, melyet 1909-ben Pécsett adtak ki. Ez a jámbor társulat eredetét a keresztúti ájtatosságtól vette, Szent Lénárt „hozta szokásba”. Kezdetben csak egyes városokban gyakorolták az üdvös ájtatosságokat, de szent Ferenc idejében XIII. Leó pápa a tagoknak búcsúkat engedélyezett. 1901-ben a társulatok örök időkre megerősítették. A tagoknak naponta kellett elmélkedniük a kapott stációról, utána pedig három Miatyánkot és Üdvözlégyet, illetve Dicsóséget kellett elmondaniuk. Ájtatosság alatt egy erre a célra megszentelt feszületet tartottak a kezükben. Minden társulat 14 tagból állt, s ennek felállítására csak a ferencrendieknek volt joguk.

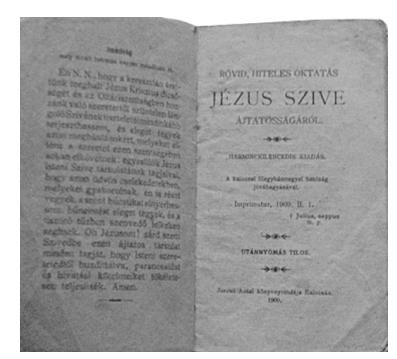

4. kép

\section{JÉZUS ISTENI SZÍVE TÁRSULAT}

A Jézus isteni Szíve Társulat könyvecskéjét Kalocsán adták ki 1909-ban. A belépési könyv utolsó oldalán tartalmazza a tag adatait. A kaplonyi kiadvány szerint Czumbil Franciska 1914. március 30-án lépett be a társulatba. A könyvecskét a leszármazottak ôrzik. $^{14}$

\section{SZENT SKAPULÁRÉ TÁRSULAT}

A Szent Skapuláré kultusza azon karmelita szerzetesektől ered, akik a Szentföldről visszatértek Európába, hogy ott kolostorokat alapítsanak, miután 1209 körül a Szentföldön megalakították a karmelita szerzetesrendet. A források szerint egy Simon nevű szerzetes volt az, akinek látomásban megjelent a Szent Szűz és átadta neki a skapulárét azzal, hogy aki ebben halálozik el, az megmenekül az örök tűztől. A Skapuláré Társulat már Simon életében megalakult. Idővel a világi hívek részére a skapulárét felváltotta két kisebb barna szövet, amelyet két szalag kötött össze. Egyiken a Kármelhegyi Boldogasszony, másikon a Jézus Szentséges Szíve képek látszottak. Később, 1900-tól ezt felváltotta egy kis érem, melynek egyik oldalába Jézus Szentséges Szíve képet, másik oldalába a Kármelhegyi Boldogasszony képét nyomták.

13 F. I. és F. M. tulajdonában.

14 Lásd a 4. sz. képet: Czumbil Franciska 1914. évi belépési könyvecskéje. F. I. és F. M. tulajdonában. 


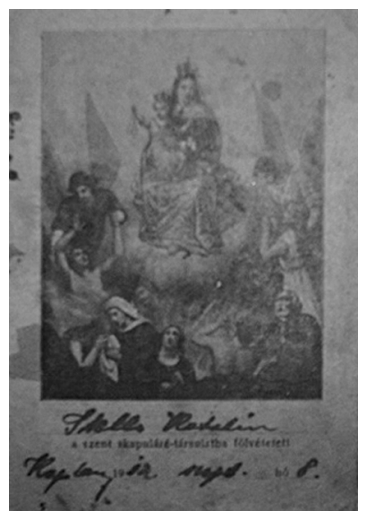

5. kép

A faluban a még élő idősek közül többen tagjai a Szent Skapuláré Társulatnak, bár belépési iratuk, lapjuk nincsen. MK (80 éves ny. tanítónő) elmondása szerint első vagy második osztályos korától tagja a társulatnak. Egy kis fémből készült, ovális alakú medaliont mutatott meg, amelyet mindennap visel a ruhája alatt a felső fehérneműjére tűzve, és arra imádkozza a három Üdvözlégy Mária imát. A medalion egyik oldalán a Kármelhegyi Boldogaszszony, a másik oldalán a Jézus Szentséges Szíve kép látható. Köztudomású, hogy 1900 óta engedélyezett a textilskapulárék használata helyett a kis méretű fémből beszélt medálok alkalmazása.

Egy másik kaplonyi családnál két belépési tagsági könyvecskét őriznek, mindkettő névre szóló: Stelli Ferenc és Stelli Katalin 1912. szeptember 8-i belépését rögzíti. ${ }^{15}$ A könyvecske első fejezete egy Rövid értesités a szent skapuláré-társulatról, amelyben jegyzik a társulat eredetét, céljait, valamint a tagság előnyeit. Ez utóbbiak közé sorolják azt, hogy az egyes tagok részesülnek a „az egész föld kerekségen levő skapuláré társulatok és egyesületek" imáiban, megóriztetnek az örök tűztől, és végül azon ígéret, hogy az elhalt társulati tagokat a Boldog Szűz a tisztító helyen vigasztalja, segíti.

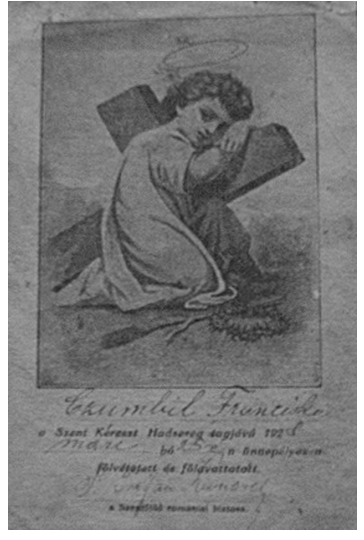

6. kép

\section{A SZENT KERESZT HADSEREGE}

A Szent Kereszt Hadseregének elterjedéséről a moldvai csángóknál Tánczos Vilmos írt két tanulmányt 2004-ben. Ô írja, hogy kevesen foglalkoztak ezzel a szervezettel, „holott ez a mozgalom a két világháború között az erdélyi katolikusok között igen jelentős volt, és széles körben elterjedt". ${ }^{16}$

A szervezet Kaplonyban is múködött: Czumbil Franciska belépési könyvecskéjét 1927. július 15-én keltezték Kaplonyban. ${ }^{17}$

A Szent Kereszt Hadserege a szomszédos Nagykárolyban is működött ebben az időben, Kaplony ennek a vonzáskörzetébe tartozott. A Nagykárolytól 3 km-re található Szentháromság-kápolna elé a harmincas években állítottak stációkat.

Ezeken feltüntették azoknak az egyesületeknek vagy magánszemélyeknek a nevét, akik az adott stáció felállítását anyagilag támogatták. A felirat szövege: Jézus dicsőségére állította a Szent-kereszt-hadsereg nagykárolyi csoportja. ${ }^{18}$

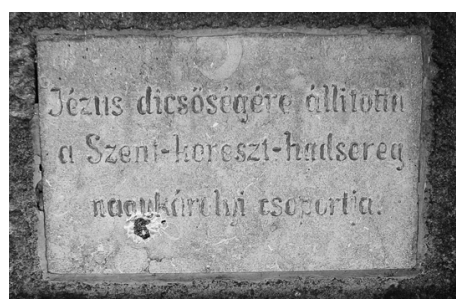

7. kép

15 Lásd az 5. sz. képet: Stelli Katalin belépési könyvecskéje 1912-ből. F. I. és F. M. tulajdonában.

16 TÁnczos 2004. a) 11-15. Ld. még Tánczos 2004. b).

17 Lásd a 6. sz. képet, a F. I. és F. M. tulajdonában.

18 Lásd a 7. számú képet. 


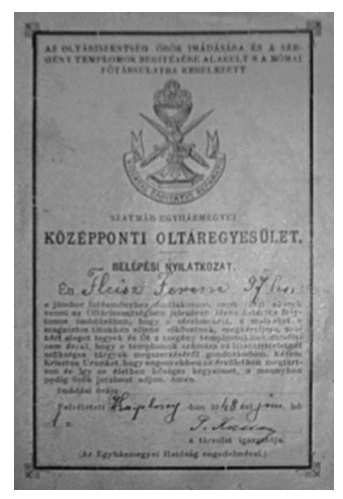

KÖZPONTI OLTÁRGYELET VAGY OLTÁREGYESÜLET

A Központi Oltáregyesületet vagy Oltáregyletet 1849-ben alapították, Magyarországon 1859-től múködött, Budapesten 1903-tól.

A társulat ugyancsak ismert volt Kaplonyban. Aktív tagsága ma nincs, régi tagsági könyvecskéket ma a leszármazottak őriznek. ${ }^{19} \mathrm{~A}$ 28 oldalas könyvecske fedőlapján tartalmazza a tag adatai: nevét, belépésének helyét és dátumát. ${ }^{20}$

Az Oltáregylet a szomszédos Nagykárolyban is múködött ebben az időben. A Szentháromság kápolna előtt az Oltáregylet is állított stációt a Szent Kereszt Hadserege említett példájára. A felirat szövege: „Az Oltáregylet elhunyt tagjainak emlékére”.

8. kép

\section{SZENT JÓZSEF TÁRSULAT}

A Szent József társulatba történő belépést igazoló irat 2013-ban került elő. A belépési könyvecske első fejezete, amely a Rövid értesítés szent József társulatáról címet viseli, arról tudósít, hogy „Szent József ezen társulata eredetileg a lincz-i (Felsô-Ausztria) karmelita atyák templomában alapíttatott, melyet IX. Piusz pápa 1856 év február 8-án kelt brevejében helyben hagyott és számos kegyelemmel és bucsuval gazdagított". ${ }^{21}$

Bár a társulat céljai között nem szerepel az, hogy az iparosok társulata lett volna, mégis akként múködött, hiszen Szent József az iparosok védőszentje. Kaplonyban máig múködik az iparosok társulata. Ezeknek saját zászlójuk van, amelyet egy iparos társulat tagjainak temetésén lehet látni. Amennyiben az iparos társulat férfi tagja elhunyt, a felesége vállalhatja azt, hogy tovább fizeti a tagsági díjat férje helyett. Ez esetben az ô temetésén is megjelenik az iparos zászló, és az iparos társulat misét mondat a lelki üdvéért. Ez ma is gyakorlat, 2013-ban volt már arra példa, hogy egy korábban elhunyt iparos feleségének temetésén megjelent az iparos társulat zászlaja.

\section{JÉZUS SZENTSÉGES SZÍVÉNEK CSALÁDJA}

A társulat 1971 óta múködik, kezdeményezője Pierre Geandron kanadai katolikus pap. „Az oltáriszentség előtt imádkozó Pierre Geandron kanadai katolikus papot 1971. augusztus 7. és 15. között Montrealban az isteni Szív sugallataival (magánkinyilatkoztatás útján) arra késztette, hogy összeállítson egy imafüzért - engesztelő kilencedet - a Szentírás alapján. Jézus (...) A Jézus Szentséges Szívének Családja 1978-ban feladatának világos megfogalmazását kapta VI. Pál pápától: »Azt kívánom, hogy a családi imádság mozgalma, amely összekapcso-

19 Lásd a 8. számú képet: Fleisz Ferenc belépési irata 1948-ból. F. I. és F. M. tulajdonában.

20 F. I. és F. M. tulajdonában.

21 Sz.n., é. n. 3. 
lódik Jézus Szentséges Szíve tiszteletének elmélyítésével, egyre nagyobb elterjedésre találjon Isten népének lelki javára«". ${ }^{22}$

Pierre Geandron a következőképpen tervezte ezeknek a csoportoknak a gyakorlatát: egyegy lelki családot tizennégy imádkozó ember alkot, melyet az úgynevezett apostol vezet. Minden tag évente háromszor végzi a kilencedet, így a tizennégy tag biztosítja, hogy az év folyamán mindennap valaki imádkozza a Jézus Szent Szívének imádságát az imafüzet alapján. Amikor egy tag a kilencedik napon befejezte az imádkozást, másvalaki kezdi el, ezzel biztosítva a folyamatosságot. ${ }^{23}$

Ez a társulat ma is működik Kaplonyban is. K. E. adatközlőm imaideje: szeptember 3-14., január 3-11., május 4-12. Nem sikerült megtudni, mikor vezették be, az adatközlő megközelítóleg 12-15 éve tagja. A tagok feladata a mindennapi ima elvégzése. Az adott imát könyvből olvasva imádkozza, utána elmondja a Jézus szíve litániát és fohászokat. Nincs adott órája ennek az imasornak, akkor imádkozza, amikor ráér. Ha unokák jelen vannak a házban, játszanak, mesélte, akkor félrehúzódik a ház egy csendes sarkába.

A fentiek rámutatnak arra, hogy Kaplonyban kiemelkedően élénk vallásos társulati tevékenység zajlott a XX. század elején. A kutatás eredményeképp 13 olyan társulatra, egyletre, egyesületre, csoportra vonatkozó írásos dokumentum vagy emlék került elő, amelyek a XX. század elején múködtek.

1. Örökös Rózsafüzér Társulat 1894-1992

2. Ferences Harmadik Rend

3. Páduai Szent Antal Imaegyesület, 1902

4. Az Élő Keresztút Társulata, 1909

5. Szent Skapuláré Társulata, 1912

6. Jézus Szentséges Szíve Társulat, 1914

7. Mária (Testvérületi) Társulat, 1927 körül

8. A Szent Kereszt Hadserege, 1927, 1928

9. Kis Szent Teréz Leányegylet, 1932

10. Katolikus legényegylet, 1932

11. Katolikus Agrárifúsági Legényegylet (KALOT), 1941

12. Oltáregyesület, 1948

13. Szent József Társulat

Ezek közül néhány társulatra csak a plébániai levéltárban fellelhető gazdasági számvetésekből vagy egyéb iratokból tudunk. Eddig nem került elő közvetlen, a faluban élő családok birtokában levő társasági tagságot igazoló irat. Páran azonban emlékeznek arra, hogy nagyobb testvéreik tagjai voltak a legényegyletnek vagy a leányegyletnek. Ezek a társulatok a következők: Mária (Testvérületi) Társulat, 1927 körül, Kis Szent Teréz Leányegylet, 1932, Katolikus legényegylet, 1932, Katolikus Agrárifúsági Legényegylet (KALOT), 1941. Más társulati iratok a falubeliek otthonából kerültek elő, kis méretű kegyképek, énekeskönyvek, családi fényképek mellől, arra utalva, hogy a leszármazottak fontosnak tartják múltjuk eme emlékeit.

22 http://ujember.katolikus.hu/Archivum/2002.11.10/0203.html, lekérdezés dátuma: 2013. ápr. 5.

23 http://ujember.katolikus.hu/Archivum/2002.11.10/0203.html, lekérdezés dátuma: 2013. ápr. 5. 
A fenti áttekintés csak a század első felében létrehozott társulatokról tesz említést, ám ezek közül néhány ma is létezik, legalábbis abban az értelemben, hogy élnek a faluban a valamikor belépett tagjai közül néhányan. Az egykor sokkal aktívabb társulatok azonban ma is hatással vannak a mindennapokra.

Kérdezhetjük, hogy vajon mennyire tartozott hozzá a társulati tagság a vallásos élet mindennapjaihoz? A válasz apró példákon keresztül fogalmazható meg. Bár 1992 után nem az Örökös, hanem az Élő Rózsafüzér Társulat szabályai szerint múködik a kaplonyi rózsafüzér társulat, többen említették, hogy a régi rózsafüzért is mondják az örökölt napon és órában. Egyik női adatközlő elmondta, hogy ő önszántából a férje imáját is felvállalta és imádkozta a férje helyett, mivel tudta róla, hogy az elfelejti, ezért nem mondja majd rendszeresen az adott időben. Az asszony tehát így gondoskodott arról, hogy az imafüzér ne szakadjon meg a férj gondatlansága okán. ${ }^{24} \mathrm{~A}$ hivatalos egyházi, társulati szabályozás folytán a hívek egy másik rendszer szerint kellene imádkozzanak. Az új társulati rend szerinti feladataikat, az Élő Rózsafüzér Társulat szabályai szerinti imaalkalmakat is teljesítik, ám egyesek továbbra is ragaszkodnak a korábbihoz, még akkor is, ha annak helyét volt hivatott felváltani az új szabályzattal érkező társulati rend.

Adatközlők:

F. I., sz. 1939

F.M, sz. 1931

H. G, sz. 1940

K.É, sz. 1950

L. F., sz. 1937

M. K., sz. 1933.

Sch. M., 1930

Kaplonyi plébánosok, akik segítették a munkámat, és akiknek köszönettel tartozom: 2007: Vik János 2008-2011: Kakuts Béla fr. Szilveszter OFM 2012-2013: Timár Sándor fr. Asztrik OFM

\section{THE RELIGIOUS LIFE IN THE VILLAGE OF SATU MARE COUNTY}

\section{Keywords: Capleni, religious associations, confraternities, relogious behaviour}

This study presents partial results of an ongoing research on the topic of daily and festive forms of religious behaviour, its organizational and its historical layers in village Capleni in Satu Mare county, Romania. In this study the author presents the religious associations of the first half of XX. century and how these associations and confraternities affected the daily life of the locals.

24 H. G. adatközlő, 2012. 


\section{VIAȚA RELIGIOASĂ ÎNTR-UN SAT SĂTMĂREAN \\ Cuvinte-cheie: Căpleni, confraternitățile religioase, organizațiile religioase, viața religioasă}

În cadrul studiului sunt prezentate rezultate partiale ale unor cercetări în curs de desfășurare. Ancheta de teren a fost efectuată în județul Satu Mare, satul Căpleni. Autoarea a studiat forme locale ale vieții religioase, în special organizațiile și confraternitățile religioase, care existau în această localitate prima jumătate a secolului XX. Studiul arată că asociațiile religioase care au funcționat în secolul XX. Căpleni prima jumătate a secolului au jucat un rol important în viața de zi cu zi a localnicilor. 